Research Paper

\title{
Association between Interleukin-18 Polymorphisms and Hepatocellular Carcinoma Occurrence and Clinical Progression
}

\author{
Hon-Kit Lau',2,\#, Ming-Ju Hsieh1,3,4,\#, Shun-Fa Yang,1,5, Hsiang-Ling Wang1,6, Wu-Hsien Kuo ${ }^{7}$, Hsiang-Lin
} Lee ${ }^{1,8}$, Chao-Bin Yeh ${ }^{9,10} \bowtie$

1. Institute of Medicine, Chung Shan Medical University, Taichung, Taiwan

2. Department of Anaesthesiology, Chung Shan Medical University Hospital, Taichung, Taiwan

3. Cancer Research Center, Changhua Christian Hospital, Changhua, Taiwan

4. Graduate Institute of Biomedical Sciences, China Medical University, Taichung, Taiwan

5. Department of Medical Research, Chung Shan Medical University Hospital, Taichung, Taiwan

6. Department of Beauty Science, National Taichung University of Science and Technology, Taichung, Taiwan

7. Department of Internal Medicine, Kaohsiung Armed Forces General Hospital, Kaohsiung, Taiwan

8. Deptartment of Surgery, Chung Shan Medical University Hospital, Taichung, Taiwan

9. Department of Emergency Medicine, School of Medicine, Chung Shan Medical University, Taichung, Taiwan

10. Department of Emergency Medicine, Chung Shan Medical University Hospital, Taichung, Taiwan

\# These authors contributed equally to the work.

$\triangle$ Corresponding author: Chao-Bin Yeh, MD, PhD. Department of Emergency Medicine, School of Medicine, Chung Shan Medical University, 110, Section 1, Chien-Kuo N. Road, Taichung, Taiwan, ROC. Fax: 886-4-24723229. E-mail: sky5ff@gmail.com

() Ivyspring International Publisher. Reproduction is permitted for personal, noncommercial use, provided that the article is in whole, unmodified, and properly cited. See http://ivyspring.com/terms for terms and conditions.

Received: 2016.04.15; Accepted: 2016.07.01; Published: 2016.07.05

\begin{abstract}
We investigated the association between interleukin-18 (IL-18) polymorphisms and the susceptibility and clinicopathological state of hepatocellular carcinoma (HCC). In total, 901 participants, including 559 healthy controls and 342 patients with $\mathrm{HCC}$, were recruited. The allelic discrimination of $-607 \mathrm{~A} / \mathrm{C}$ ( $\mathrm{rs} 1946518)$ and $-137 \mathrm{G} / \mathrm{C}$ (rs 187238) polymorphisms of IL-l8 was assessed through real-time polymerase chain reaction by performing the TaqMan assay. The IL- 18 $-137 \mathrm{G} / \mathrm{C}$ polymorphism but not the $-607 \mathrm{~A} / \mathrm{C}$ polymorphism showed a significant association with the risk of HCC. Participants carrying the IL-18 -137 polymorphism with heterozygous G/C and homozygous CC genotypes showed a 1.987 -fold increase $(95 \% \mathrm{Cl}=1.301-3.032 ; p=0.001)$ in the risk of HCC compared with those homozygous for wild-type G/G. The 342 patients with HCC carrying the IL-18-137G/C polymorphism were positive for hepatitis B virus (HBV) infection with an adjusted odds ratio of 1.668. Moreover, the $142 \mathrm{HBV}$ positive patients with $\mathrm{HCC}$ and the $I L-18$ -137 polymorphism were positive for at least one $C$ genotype and showed significant vascular invasion $(p=0.018)$. Furthermore, the level of $\alpha$-fetoprotein was high in the patients carrying the IL-18 -137 polymorphism with GC+CC alleles $(p=0.011)$. In conclusion, the IL-18 -137G/C polymorphism with a $\mathrm{GC}+\mathrm{CC}$ genotype could be a factor that increases the risk of HCC. Furthermore, the correlation between the IL-18-137G/C polymorphism and HCC-related HBV infection is a risk factor for vascular invasion and has a synergistic effect that can further enhance HCC prognosis.
\end{abstract}

Key words: hepatocellular carcinoma; interleukin-18; hepatitis B virus

\section{Introduction}

Hepatocellular carcinoma (HCC) is a primary malignancy of the liver; it is a major threat to human health and has poor prognosis. HCC is the fifth and seventh most frequent cancer in men and women worldwide, respectively, and is the third and second leading cause of cancer related deaths worldwide and 
in Taiwan, respectively [1, 2]. Major risk factors for HCC include infections of hepatitis B virus (HBV) and hepatitis $\mathrm{C}$ virus (HCV), exposure to substances (e.g., alphatoxins) that are toxic to the liver, and alcohol and tobacco consumption. Moreover, immune system-mediated chronic inflammation of the liver can lead to HCC [3-5]. In addition, various inflammatory cytokines, such as Interleukins (IL)-1 $\beta$, $-18,-6[3-5]$, and $-17[3,6,7]$, participate in chronic hepatic inflammation, leading to tumorigenesis. Tangkijvanich et al. [8] reported that the serum level of IL-18 is a useful biological marker of tumor invasiveness and an independent prognostic factor for survival among patients with HCC. Shiraki et al. [9] reported that the serum level of IL-18 increased in patients with HCV-related stage IV HCC compared with patients with earlier-stage HCC. Although genetic predisposition is one of the factors critical for HCC progression, few studies have focused on IL-18 single nucleotide polymorphisms (SNPs) in patients with HCC. Moreover, research on the combined effect of IL-18 SNPs and HBV infection on the risk and clinicopathologic development of HCC remain scant.

IL-18, an 18-kDa cytokine, originally known as interferon- $\gamma($ IFN- $\gamma)$-inducing factor, shares structural and functional properties with IL-1. This cytokine is mainly produced by activated macrophages and Kupffer cells and can promote IFN- $\gamma$ production [10, 11]. $I L-18$ is located on chromosome 11q23. 1 and contains six exons spanning over $20.8 \mathrm{~kb}$ and five introns $[12,13]$. Several SNPs in the promoter region and two polymorphisms in the 5'-nontranslated region of IL-18 have been identified [12, 14-16]. Among these, two functional polymorphisms in the promoter region at loci $-607 \mathrm{~A} / \mathrm{C}$ and $-137 \mathrm{G} / \mathrm{C}$ are the most studied. The structure of IL-18 promoter suggests that transcription factor PU.1 might be a critical regulator of its activity [17]. Serum levels of IL-18 may influence the risk of coronary artery disease and asthma and is a crucial event in oral carcinoma cells for oncogenesis [10, 18]. Thompson et al. [17] revealed the influence of serum levels of IL-18 on the risk of diseases and reported that variations in IL-18 may influence IL-18 synthesis. Moreover, Lebel-Binay et al. [19] reported that improper synthesis of IL-18 contributes to cancer pathogenesis and may influence the clinical outcome in patients. In addition, SNP is the most common type of DNA sequence variation, influencing the occurrence and progression of gene-related hepatocarcinogenesis. Our previous studies reported that SNPs in CD44, fibroblast growth factor receptor 4, intercellular adhesion molecule-1, metallothionein-1, reversion-inducing-cysteine-rich protein with Kazal motifs, and CCR2 genes may predict the risk of HCC [20-25]. However, few studies have focused on IL-18 SNPs in patients with HCC who are HBV positive. Therefore, the aim of this study was to identify IL-18 polymorphisms specifically in patients showing HBV-related susceptibility and clinicopathological status of HCC.

\section{Materials and Methods}

\section{Patients}

In this study, we recruited 342 patients with HCC at the Chung Shan Medical University Hospital, Taiwan. A diagnosis of HCC was made according to the criteria specified in the national guidelines for HCC detection. All 559 control subjects were recruited at the same hospital and these control groups had neither self-reported history of cancer of any sites. Personal information and characteristics collected from the study subjects using intervieweradministered questionnaires contained questions involving demographic characteristics. All the subjects in the study were Han Chinese with the same ethnicity. The blood samples which obtained from the controls and HCC patients were stored in EDTA tubes, centrifuged immediately and stored at $-80^{\circ} \mathrm{C}$. The Institutional Review Board of Chung Shan Medical University Hospital approved this study (CSMUH No: CS15099), and informed written consent was obtained from each participant.

\section{Selection of IL-18 Polymorphisms}

A total of two SNPs in IL-18 were selected from the International HapMap Project data for this study. We included -607A/C (rs1946518) and IL-18 -137G/C (rs187238) in the promoter region which were selected in this study since these 2 SNPs were found to modify the binding affinities [17].

\section{DNA extraction and quantitative real-time PCR}

Genomic DNA was extracted from EDTA anti-coagulated venous blood using a QIAamp DNA blood mini kit based on the manufacturer's protocol as described in detail previously [26]. Allelic discrimination of $-607 A / C$ (rs1946518) and $-137 G / C$ (rs187238) polymorphisms of the IL-18 gene was assessed with the ABI StepOne ${ }^{\mathrm{TM}}$ Real-Time PCR System (Applied Biosystems, Foster City , CA , USA) and analyzed using SDS vers. 3.0 software (Applied Biosystems), with the TaqMan assay [18].

\section{Statistical analysis}

The distributions of demographic characteristics and genotype frequencies for different genotypes between the study participants and controls were analyzed using the chi-square test for certain categories of variables. Student's $t$-test was used to 
evaluate the differences in the laboratory findings between the 2 groups. The odds ratios (ORs) and their $95 \%$ confidence intervals (CIs) of the association between the genotype frequencies and HCC were estimated using multiple logistic regression models by controlling for covariates. A $p$ value of less than 0.05 was considered statistically significant. The data were analyzed using SPSS 12.0 statistical software.

\section{Results}

Demographic characteristics and clinical parameters of the 559 healthy controls and 342 patients with HCC are summarized in Table 1. The mean age (SD) in the control and patient groups was $51.86 \pm 14.71$ and $62.96 \pm 11.67$ years, respectively. The patients with HCC were predominantly older males (71.3\%). The genotypic distributions and associations between patients with HCC and healthy controls carrying the IL-18 polymorphisms, $-607 \mathrm{~A} / \mathrm{C}$ (rs1946518) and -137G/C (rs187238), are listed in Table 2. In our recruited control group, the frequencies of $I L-18-607 \mathrm{~A} / \mathrm{C}\left(\chi^{2}\right.$ value: 0.080, $p=0.777)$ and $-137 \mathrm{G} / \mathrm{C}\left(\chi^{2}\right.$ value: $\left.0.803, p=0.370\right)$ were in Hardy-Weinberg equilibrium, respectively.

After adjusting for the covariates of age, sex, and alcohol consumption, the IL-18 -137G/C (rs187238) polymorphism genotypes, GC+CC and GG, in the healthy controls and patients with HCC differed significantly (adjusted odds ratio $[\mathrm{AOR}]=1.987 ; 95 \%$ confidence interval $[\mathrm{CI}]=1.301-3.032 ; p<0.001$ ).

Table 3 shows the distribution frequency of the IL-18 -137 polymorphism among the 342 patients with HCC along with the clinical status. The patients with HCC were evaluated to understand the influence of $I L-18-137$ polymorphism genotypes, GC+CC and GG, on the clinical TNM stage, primary tumor size, lymph node involvement, distant metastasis, vascular invasion, Child-Pugh grade, presence of an HBV or $\mathrm{HCV}$ infection, and liver cirrhosis. No significant differences were observed in the influence of the aforementioned $I L-18-137$ polymorphism genotypes on the clinical TNM stage and clinical variables, except for HBV infection (GC+CC vs GG; $A O R=$ $1.668 ; 95 \% \mathrm{CI}=1.001-2.786 ; p<0.05)$.

In addition, we explored the potential association between the IL-18 -137 polymorphism genotypes, GC+CC and GG, in the patients with HCC who were HBV positive (Table 4). Among the 142 patients with HCC who were HBV positive, significant vascular invasion was observed in those carrying $I L-18-137$ polymorphism genotype GC+CC compared with those carrying GG genotype $(\mathrm{AOR}=$ $2.825 ; 95 \% \mathrm{CI}=1.168-6.833 ; p=0.018)$. As shown in Table 5, the level of a-fetoprotein differed significantly $(p<0.05)$ in the patients with HCC under the influence of IL-18 $-137 \mathrm{G} / \mathrm{C}$ polymorphism genotypes GG and GC+CC. The other clinicopathological statuses for HCC, including ALT, AST, and AST/ALT ratio, showed no significant differences.

Table 1. The distributions of demographical characteristics and clinical parameters in 559 controls and 342 patients with HCC.

\begin{tabular}{llll}
\hline Variable & Controls (N=559) & Patients (N=342) & $p$ value \\
\hline Age (yrs) & Mean \pm S.D. & Mean \pm S.D. & \\
& $51.86 \pm 14.71$ & $62.96 \pm 11.67$ & $p<0.001$ \\
Gender & $\mathbf{n}(\%)$ & $\mathbf{n}(\%)$ & \\
Male & $456(81.6 \%)$ & $244(71.3 \%)$ & \\
Female & $103(18.4 \%)$ & $98(28.7 \%)$ & $p<0.001$ \\
Alcohol consumption & & & \\
No & $345(61.7 \%)$ & $217(63.5 \%)$ & \\
Yes & $214(38.3 \%)$ & $125(36.5 \%)$ & $p=0.602$ \\
Tobacco consumption & & & \\
No & $339(60.6 \%)$ & $205(59.9 \%)$ & \\
Yes & $220(39.4 \%)$ & $137(40.1 \%)$ & $p=0.834$ \\
Stage & & & \\
I+II & & $224(65.5 \%)$ & \\
III+IV & & $118(34.5 \%)$ & \\
Tumor T status & & & \\
$\leq$ T2 & & $228(66.7 \%)$ & \\
$>$ T2 & & $114(33.3 \%)$ & \\
Lymph node status & & & \\
N0 & & $330(96.5 \%)$ & \\
N1+N2 & & $12(3.5 \%)$ & \\
Metastasis & & $324(94.7 \%)$ & \\
M0 & & $18(5.3 \%)$ & \\
M1 & & $282(82.5 \%)$ & \\
vascular invasion & & $60(17.5 \%)$ & \\
No & & & \\
Yes & & & \\
\hline
\end{tabular}

Table 2. Distribution frequency of IL-I8 genotypes in 559 controls and 342 patients with HCC.

\begin{tabular}{|c|c|c|c|c|}
\hline Variable & $\begin{array}{l}\text { Controls } \\
(\mathrm{N}=559) \mathrm{n} \\
(\%)\end{array}$ & $\begin{array}{l}\text { Patients } \\
(\mathrm{N}=342) \mathrm{n} \\
(\%)\end{array}$ & OR $(95 \%$ CI) & AOR $(95 \% \mathrm{CI})$ \\
\hline \multicolumn{5}{|c|}{$\begin{array}{l}\text { IL-18 -607A/C } \\
\text { (rs1946518) }\end{array}$} \\
\hline AA & $148(26.5 \%)$ & $88(25.7 \%)$ & 1.00 & 1.00 \\
\hline $\mathrm{AC}$ & $276(49.4 \%)$ & $167(48.8 \%)$ & $\begin{array}{l}1.018 \\
(0.734-1.410)\end{array}$ & $\begin{array}{l}0.978 \\
(0.670-1.427)\end{array}$ \\
\hline $\mathrm{CC}$ & $135(24.1 \%)$ & $87(25.5 \%)$ & $\begin{array}{l}1.084 \\
(0.743-1.580)\end{array}$ & $\begin{array}{l}1.274 \\
(0.818-1.982)\end{array}$ \\
\hline $\mathrm{AC}+\mathrm{CC}$ & $411(73.5 \%)$ & $254(74.3 \%)$ & $\begin{array}{l}1.039 \\
(0.765-1.412)\end{array}$ & $\begin{array}{l}1.065 \\
(0.747-1.520)\end{array}$ \\
\hline \multicolumn{5}{|c|}{$\begin{array}{l}\text { IL-18 -137G/C } \\
\text { (rs187238) }\end{array}$} \\
\hline GG & $476(85.2 \%)$ & 266 (77.8\%) & 1.00 & 1.00 \\
\hline GC & $78(13.9 \%)$ & $73(21.3 \%)$ & $\begin{array}{l}1.675 \\
(1.177-2.383)^{*}\end{array}$ & $\begin{array}{l}2.066 \\
(1.337-3.191)^{*}\end{array}$ \\
\hline $\mathrm{CC}$ & $5(0.9 \%)$ & $3(0.9 \%)$ & $\begin{array}{l}1.074 \\
(0.255-4.528)\end{array}$ & $\begin{array}{l}1.054 \\
(0.201-5.524)\end{array}$ \\
\hline $\mathrm{GC}+\mathrm{CC}$ & $83(14.8 \%)$ & $76(22.2 \%)$ & $\begin{array}{l}1.639 \\
(1.160-2.315)^{*}\end{array}$ & $\begin{array}{l}1.987 \\
(1.301-3.032)^{*}\end{array}$ \\
\hline
\end{tabular}

The odds ratios (ORs) and with their $95 \%$ confidence intervals (CIs) were estimated by logistic regression models. The adjusted odds ratios (AORs) with their $95 \%$ confidence intervals (CIs) were estimated by multiple logistic regression models after controlling for age, gender, alcohol and tobacco consumption.

${ }^{*} p$ value $<0.05$ as statistically significant. 
Table 3. Odds ratio $(\mathrm{OR})$ and $95 \%$ confidence interval $(\mathrm{Cl})$ of clinical status and IL-I8 -137G/C genotypic frequencies in 342 HCC patients.

\begin{tabular}{|c|c|c|c|c|}
\hline \multirow[t]{2}{*}{ Variable } & \multicolumn{4}{|c|}{ Genotypic frequencies } \\
\hline & GG $(N=266)$ & $\mathrm{GC}+\mathrm{CC}(\mathrm{N}=76)$ & OR $(95 \% \mathrm{CI})$ & $p$ value \\
\hline \multicolumn{5}{|c|}{ Clinical Stage } \\
\hline Stage I/II & $176(66.2 \%)$ & $48(63.2 \%)$ & 1.00 & $p=0.627$ \\
\hline Stage III/IV & $90(33.8 \%)$ & $28(36.8 \%)$ & $1.141(0.671-1.940)$ & \\
\hline \multicolumn{5}{|l|}{ Tumor size } \\
\hline$\leqq \mathrm{T} 2$ & $180(67.7 \%)$ & $48(63.2 \%)$ & 1.00 & $p=0.462$ \\
\hline$>\mathrm{T} 2$ & $86(32.3 \%)$ & $28(36.8 \%)$ & $1.221(0.717-2.079)$ & \\
\hline \multicolumn{5}{|l|}{$\begin{array}{l}\text { Lymph node } \\
\text { metastasis }\end{array}$} \\
\hline No & $256(96.2 \%)$ & $74(97.4 \%)$ & 1.00 & $p=0.637$ \\
\hline Yes & $10(3.8 \%)$ & $2(2.6 \%)$ & $0.692(0.148-3.228)$ & \\
\hline \multicolumn{5}{|l|}{$\begin{array}{l}\text { Distant } \\
\text { metastasis }\end{array}$} \\
\hline No & $253(95.1 \%)$ & $71(93.4 \%)$ & 1.00 & $p=0.560$ \\
\hline Yes & $13(4.9 \%)$ & $5(6.6 \%)$ & $1.371(0.473-3.974)$ & \\
\hline \multicolumn{5}{|l|}{$\begin{array}{l}\text { Vascular } \\
\text { invasion }\end{array}$} \\
\hline No & $222(83.5 \%)$ & $60(78.9 \%)$ & 1.00 & $p=0.362$ \\
\hline Yes & $44(16.5 \%)$ & $16(21.1 \%)$ & $1.345(0.710-2.550)$ & \\
\hline \multicolumn{5}{|l|}{$\begin{array}{l}\text { Child-Pugh } \\
\text { grade }\end{array}$} \\
\hline A & $206(77.4 \%)$ & $54(71.1 \%)$ & 1.00 & $p=0.250$ \\
\hline $\mathrm{B}$ or $\mathrm{C}$ & $60(22.6 \%)$ & $22(28.9 \%)$ & $1.399(0.789-2.481)$ & \\
\hline \multicolumn{5}{|l|}{ HBsAg } \\
\hline Negative & $163(61.3 \%)$ & $37(48.7 \%)$ & 1.00 & $p=0.049^{*}$ \\
\hline Positive & $103(38.7 \%)$ & $39(51.3 \%)$ & $1.668(1.001-2.786)$ & \\
\hline \multicolumn{5}{|l|}{ Anti-HCV } \\
\hline Negative & $136(51.1 \%)$ & $42(55.3 \%)$ & 1.00 & $p=0.525$ \\
\hline Positive & $130(48.9 \%)$ & $34(44.7 \%)$ & $0.847(0.507-1.413)$ & \\
\hline \multicolumn{5}{|c|}{ Liver cirrhosis } \\
\hline Negative & $53(19.9 \%)$ & $15(19.7 \%)$ & 1.00 & $p=0.971$ \\
\hline Positive & $213(80.1 \%)$ & $61(80.3 \%)$ & $1.012(0.534-1.919)$ & \\
\hline
\end{tabular}

The ORs with analyzed by their $95 \%$ CIs were estimated by logistic regression models.

$>$ T2: multiple tumor more than $5 \mathrm{~cm}$ or tumor involving a major branch of the portal or hepatic vein(s)

${ }^{*} p$ value $<0.05$ as statistically significant.
Table 4. Odds ratio $(\mathrm{OR})$ and $95 \%$ confidence interval $(\mathrm{Cl})$ of clinical status and IL-18 -137G/C genotypic frequencies in 142 $\mathrm{HCC}$ patients with $\mathrm{HBsAg}$ positive.

\begin{tabular}{|c|c|c|c|c|}
\hline \multirow[t]{2}{*}{ Variable } & \multicolumn{2}{|c|}{ Genotypic frequencies } & \multirow[b]{2}{*}{ OR $(95 \% \mathrm{CI})$} & \multirow[b]{2}{*}{$p$ value } \\
\hline & $\begin{array}{l}\text { GG } \\
(N=103)\end{array}$ & $\begin{array}{l}\text { GC+CC } \\
(\mathrm{N}=39)\end{array}$ & & \\
\hline \multicolumn{5}{|c|}{ Clinical Stage } \\
\hline Stage I/II & $68(66.0 \%)$ & $20(51.3 \%)$ & 1.00 & $p=0.106$ \\
\hline Stage III/IV & $35(34.0 \%)$ & $19(48.7 \%)$ & $\begin{array}{l}1.846 \\
(0.873-3.902)\end{array}$ & \\
\hline \multicolumn{5}{|l|}{ Tumor size } \\
\hline$\leqq \mathrm{T} 2$ & $70(68.0 \%)$ & $20(51.3 \%)$ & 1.00 & $p=0.066$ \\
\hline$>\mathrm{T} 2$ & $33(32.0 \%)$ & $19(48.7 \%)$ & $\begin{array}{l}2.015 \\
(0.950-4.275)\end{array}$ & \\
\hline \multicolumn{5}{|l|}{$\begin{array}{l}\text { Lymph node } \\
\text { metastasis }\end{array}$} \\
\hline No & $99(96.1 \%)$ & $37(94.9 \%)$ & 1.00 & $p=0.742$ \\
\hline Yes & $4(3.9 \%)$ & $2(5.1 \%)$ & $\begin{array}{l}1.338 \\
(0.235-7.614)\end{array}$ & \\
\hline \multicolumn{5}{|c|}{ Distant metastasis } \\
\hline No & $96(93.2 \%)$ & $35(89.7 \%)$ & 1.00 & $p=0.491$ \\
\hline Yes & $7(6.8 \%)$ & $4(10.3 \%)$ & $\begin{array}{l}1.567 \\
(0.432-5.682)\end{array}$ & \\
\hline \multicolumn{5}{|c|}{ Vascular invasion } \\
\hline No & $89(86.4 \%)$ & $27(69.2 \%)$ & 1.00 & $p=0.018^{*}$ \\
\hline Yes & $14(13.6 \%)$ & $12(30.8 \%)$ & $\begin{array}{l}2.825 \\
(1.168-6.833)\end{array}$ & \\
\hline \multicolumn{5}{|c|}{ Child-Pugh grade } \\
\hline A & $81(78.6 \%)$ & $25(64.1 \%)$ & 1.00 & $p=0.075$ \\
\hline B or C & $22(21.4 \%)$ & $14(35.9 \%)$ & $\begin{array}{l}2.062 \\
(0.921-4.618)\end{array}$ & \\
\hline \multicolumn{5}{|l|}{ Anti-HCV } \\
\hline Negative & $88(85.4 \%)$ & $33(84.6 \%)$ & 1.00 & $p=0.902$ \\
\hline Positive & $15(14.6 \%)$ & $6(15.4 \%)$ & $\begin{array}{l}1.067 \\
(0.382-2.981)\end{array}$ & \\
\hline \multicolumn{5}{|c|}{ Liver cirrhosis } \\
\hline Negative & $14(13.6 \%)$ & $9(23.1 \%)$ & 1.00 & $p=0.171$ \\
\hline Positive & $89(86.4 \%)$ & $30(76.9 \%)$ & $\begin{array}{l}0.524 \\
(0.206-1.334)\end{array}$ & \\
\hline
\end{tabular}

The ORs with analyzed by their $95 \%$ CIs were estimated by logistic regression models.

$>$ T2: multiple tumor more than $5 \mathrm{~cm}$ or tumor involving a major branch of the portal or hepatic vein(s)

${ }^{*} p$ value $<0.05$ as statistically significant.

\section{Discussion}

Compared with healthy people, the serum level of IL-18 in patients with HCC is controversial. Tangkijvanich et al. [8] and Mohran et al. [27] reported that IL-18 levels in patients with HCC were significantly higher than those in healthy controls. However, Bao et al. [12] showed that the level of serum IL-18 were significantly lower in patients with HCC than in healthy people. In addition, they reported that the IL-18 $-137 \mathrm{G} / \mathrm{C}$ polymorphism was significantly correlated with the risk of HCC; however, IL-18 SNPs were not associated with the serum concentration of IL-18. Thus, we suggested that serum levels of IL-18 may be distinct in various diseases and cancer stages. In addition, we revealed that the genetic of patients profile is one of the key factors for the serum level of IL-18 to regulate the development of HCC. In our study, the presence of IL-18 -607A/C (rs1946518) and -137G/C (rs187238) 
polymorphisms was analyzed in 559 healthy controls and 342 patients with HCC. The number of patients with HCC carrying the IL-18 -137G/C (rs187238) polymorphism genotypes GC+CC and GG differed significantly $(p<0.001)$. Our results confirmed that patients carrying the IL-18 $-137 \mathrm{G} / \mathrm{C}$ polymorphism genotype GC+CC have a high risk of HCC, similar to the results obtained by Bao et al [12], reporting a significant association between the IL-18 -137G/C polymorphism and the risk of HCC, where a high frequency of the $\mathrm{G}$ allele was associated with an increased risk of HCC.

No association between the IL-18 -137 polymorphism genotypes $\mathrm{GC}+\mathrm{CC}$ and $\mathrm{GG}$ and the aforementioned clinical parameters except HBV infection was observed in our study. We found that among the patients with HCC who were HBV positive, the risk of HCC was higher in those who were carrying the IL-18-137 polymorphism genotype GC+CC $(39 / 76=51.3 \%)$ than those who were carrying the GG genotype $(103 / 266=38.7 \%)$ with an AOR of $1.668(p<0.05)$. This result is similar to the results of a study performed by Bouzgarrou et al. [28], reporting that a polymorphism in $\mathrm{C}$ allele at position $-607(\mathrm{CC}+\mathrm{C} / \mathrm{A})$ was associated with an increased risk of cirrhosis and $\mathrm{HCC}$ in patients who were $\mathrm{HBV}$ positive. Because HBV infection can lead to severe liver diseases, such as chronic hepatitis, cirrhosis, and HCC $[29,30]$, the natural course of HBV infection is probably associated with host immune factors, and IL-18 is crucial in immune defense. Kim et al. [31] showed that the $-148 \mathrm{C},+8925 \mathrm{G}$, and $+13925 \mathrm{C}$ alleles of $I L-18$ are associated with the development of HCC, and the $-148 \mathrm{G}>\mathrm{C}$ SNP was functionally essential in determining the disease outcome. However, the association between IL-18 SNP and HBV-related HCC has been studies seldom. Karra et al. [32] reported that polymorphisms in the $I L-18$ promoter region at positions -607 and -137 combining with HBV infection can be associated with various outcomes, including spontaneous recovery, chronic hepatitis, liver cirrhosis, and HCC. Therefore, as reported by Thio et al. [33], the genetic background of an individual might influence the clinical outcome of $\mathrm{HBV}$ infection. Interestingly, in a meta-analysis, Yang et al. suggested that IL-18 - 137G/C polymorphism, but not $-607 \mathrm{C} / \mathrm{A}$ polymorphism, was associated with chronic hepatitis $\mathrm{C}$ virus infections [34]. Coordinating innate and adaptive humoral and cell-mediated immunities, various cytokines, such as IL-18, and associations with SNPs may reveal some clues in some spontaneous clearance, while others develop cirrhosis and liver cancer; these results can provide new clues to explain the mechanism of $\mathrm{HBV}$ infection $[35,36]$.
An advanced statistics on the 142 patients with HCC who were HBV positive revealed that the GC genotype and $C$ allele of the $I L-18-137$ SNP were associated with a significantly increased risk of vascular invasion compared with the GG genotype and $G$ allele. Migita et al. [37] reported that the polymorphisms at -607 and -137 in the IL-18 promoter region may affect the development and progression of HBV-related liver diseases; we obtained similar results with an AOR of $2.825(p=$ 0.018). Moreover, Kim et al. [31] confirmed that the $-148 \mathrm{C}$, $+8925 \mathrm{G}$, and $+13925 \mathrm{C}$ alleles of $\mathrm{IL}-18$ in patients with $\mathrm{HBV}$ infection are associated with the presence of $\mathrm{HCC}$, and the 148G $>$ C SNP is functionally crucial in determining the disease outcome. However, Chung et al. [38] reported that IL-18 and IL-18R polymorphisms may contribute to the development and lymph node metastasis of papillary thyroid carcinoma. We revealed that the IL-18 -137C polymorphism can be a crucial factor for the risk of HBV-related HCC outcome of vascular invasion. Moreover, IL-18 and IL-18R polymorphisms in various cancers have different influence on the outcomes and specific characteristic phenomena. Perrella et al. [39] reported no significant difference among patients with HCC and no correlation between cytokines and other evaluated variables, such as HCV infection, RNA, a-fetoprotein, genotype, and demographic characteristics of patients with HCC. Our results suggest that the clinicopathological statuses for HCC, including ALT, AST, and AST/ALT ratio, showed no significant differences except the a-fetoprotein level. The level of a-fetoprotein was significantly associated with the presence of the $I L-18$ $-137 \mathrm{G} / \mathrm{C}$ polymorphism genotypes GG and GC+CC in the patients with HCC $(p<0.05)$. Therefore, the IL-18 -137G/C polymorphism might be crucial for the pathogenesis of $\mathrm{HCC}$, and the $\mathrm{GC}+\mathrm{CC}$ genotype in the IL-18 -137 SNP combining with a-fetoprotein levels can be utilized as markers for an early diagnosis of HCC.

In conclusion, our results confirmed that the IL-18 -137G/C (rs187238) SNP can be a factor that increases the risk of HCC. Moreover, the association of the GC genotype of the $I L-18-137$ SNP with HBV-related HCC can increase the risk of vascular invasion. In addition, the a-fetoprotein level combined with the $I L-18-137$ SNP can be utilized as a marker for the early diagnosis of HCC.

\section{Acknowledgment}

This study was supported by research grants from Chung Shan Medical University Hospital (CSH-2016-C-019). 


\section{Competing Interests}

The authors have declared that no competing interest exists.

\section{References}

[1] Jemal A, Bray F, Center MM, Ferlay J, Ward E and Forman D. Global cancer statistics. CA Cancer J Clin 2011; 61: 69-90.

[2] Bosetti C, Turati F and La Vecchia C. Hepatocellular carcinoma epidemiology. Best Pract Res Clin Gastroenterol 2014; 28: 753-770.

[3] Li S, Sun R, Chen Y, Wei H and Tian Z. TLR2 limits development of hepatocellular carcinoma by reducing IL18-mediated immunosuppression. Cancer Res 2015; 75: 986-995.

[4] Naugler WE, Sakurai T, Kim S, Maeda S, Kim K, Elsharkawy AM and Karin M. Gender disparity in liver cancer due to sex differences in MyD88-dependent IL-6 production. Science 2007; 317: 121-124.

[5] He G, Dhar D, Nakagawa H, Font-Burgada J, Ogata H, Jiang Y, Shalapour S, Seki E, Yost SE, Jepsen K, Frazer KA, Harismendy O, Hatziapostolou M, Iliopoulos D, Suetsugu A, Hoffman RM, Tateishi R, Koike K and Karin M. Identification of liver cancer progenitors whose malignant progression depends on autocrine IL-6 signaling. Cell 2013; 155: 384-396.

[6] Gu FM, Li QL, Gao Q, Jiang JH, Zhu K, Huang XY, Pan JF, Yan J, Hu JH, Wang Z, Dai Z, Fan J and Zhou J. IL-17 induces AKT-dependent IL-6/JAK2/STAT3 activation and tumor progression in hepatocellular carcinoma. Mol Cancer 2011; 10: 150 .

[7] Zhang JP, Yan J, Xu J, Pang XH, Chen MS, Li L, Wu C, Li SP and Zheng L. Increased intratumoral IL-17-producing cells correlate with poor survival in hepatocellular carcinoma patients. J Hepatol 2009; 50: 980-989.

[8] Tangkijvanich P, Thong-Ngam D, Mahachai V, Theamboonlers A and Poovorawan Y. Role of serum interleukin-18 as a prognostic factor in patients with hepatocellular carcinoma. World J Gastroenterol 2007; 13: 4345-4349.

[9] Shiraki T, Takayama E, Magari H, Nakata T, Maekita T, Enomoto S, Mori Y, Shingaki N, Moribata K, Deguchi H, Ueda K, Inoue I, Mizuno-Kamiya M, Yashiro K, Iguchi M, Tamai H, Kameyama Y, Kato J, Kondoh N and Ichinose $\mathrm{M}$. Altered cytokine levels and increased CD4+CD57+ T cells in the peripheral blood of hepatitis $C$ virus-related hepatocellular carcinoma patients. Oncol Rep 2011; 26: 201-208.

[10] Yue M, Wang JJ, Tang SD, Feng L, Zhang Y, Liu Y, Wang J, Deng XZ, Xu K and Zhang J. Association of interleukin-18 gene polymorphisms with the outcomes of hepatitis $C$ virus infection in high-risk Chinese Han population. Immunol Lett 2013; 154: 54-60.

[11] Dinarello CA. IL-18: A TH1-inducing, proinflammatory cytokine and new member of the IL-1 family. J Allergy Clin Immunol 1999; 103: 11-24.

[12] Bao J, Lu Y, Deng Y, Rong C, Liu Y, Huang X, Song L, Li S and Qin X. Association between IL-18 polymorphisms, serum levels, and HBV-related hepatocellular carcinoma in a Chinese population: a retrospective case-control study. Cancer Cell Int 2015; 15: 72.

[13] Kruse S, Kuehr J, Moseler M, Kopp MV, Kurz T, Deichmann KA, Foster PS and Mattes J. Polymorphisms in the IL 18 gene are associated with specific sensitization to common allergens and allergic rhinitis. J Allergy Clin Immunol 2003; 111: 117-122.

[14] Lu Y, Bao JG, Deng Y, Rong CZ, Liu YQ, Huang XL, Song LY, Li S and Qin X. Role of IL-18 Gene Promoter Polymorphisms, Serum IL-18 Levels, and Risk of Hepatitis B Virus-related Liver Disease in the Guangxi Zhuang Population: a Retrospective Case-Control Study. Asian Pac J Cancer Prev 2015; 16: 6019-6026.

[15] Giedraitis V, He B, Huang WX and Hillert J. Cloning and mutation analysis of the human IL-18 promoter: a possible role of polymorphisms in expression regulation. J Neuroimmunol 2001; 112: 146-152.

[16] Jia Y, Zang A, Jiao S, Chen S and Yan F. The interleukin-18 gene promoter -607 $\mathrm{A} / \mathrm{C}$ polymorphism contributes to non-small-cell lung cancer risk in a Chinese population. Onco Targets Ther 2016; 9: 1715-1719.

[17] Thompson SR and Humphries SE. Interleukin-18 genetics and inflammatory disease susceptibility. Genes Immun 2007; 8: 91-99.

[18] Tsai HT, Hsin CH, Hsieh YH, Tang CH, Yang SF, Lin CW and Chen MK. Impact of interleukin-18 polymorphisms $-607 \mathrm{~A} / \mathrm{C}$ and $-137 \mathrm{G} / \mathrm{C}$ on oral cancer occurrence and clinical progression. PLoS One 2013; 8: e83572.

[19] Lebel-Binay S, Berger A, Zinzindohoue F, Cugnenc P, Thiounn N, Fridman $\mathrm{WH}$ and Pages F. Interleukin-18: biological properties and clinical implications. Eur Cytokine Netw 2000; 11: 15-26.

[20] Chen TP, Lee HL, Huang YH, Hsieh MJ, Chiang WL, Kuo WH, Chou MC, Yang SF and Yeh CB. Association of intercellular adhesion molecule-1 single nucleotide polymorphisms with hepatocellular carcinoma susceptibility and clinicopathologic development. Tumour Biol 2015;

[21] Chung TT, Yeh CB, Li YC, Su SC, Chien MH, Yang SF and Hsieh YH. Effect of RECK gene polymorphisms on hepatocellular carcinoma susceptibility and clinicopathologic features. PLoS One 2012; 7: e33517.

[22] Sheu MJ, Hsieh MJ, Chiang WL, Yang SF, Lee HL, Lee LM and Yeh CB. Fibroblast growth factor receptor 4 polymorphism is associated with liver cirrhosis in hepatocarcinoma. PLoS One 2015; 10: e0122961.
[23] Su SC, Hsieh MI, Chou YE, Fan WL, Yeh CB and Yang SF. Effects of RAGE Gene Polymorphisms on the Risk and Progression of Hepatocellular Carcinoma. Medicine (Baltimore) 2015; 94: e1396.

[24] Wong RH, Huang CH, Yeh CB, Lee HS, Chien MH and Yang SF. Effects of metallothionein-1 genetic polymorphism and cigarette smoking on the development of hepatocellular carcinoma. Ann Surg Oncol 2013; 20: 2088-2095.

[25] Yeh CB, Tsai HT, Chen YC, Kuo WH, Chen TY, Hsieh YH, Chou MC and Yang SF. Genetic polymorphism of CCR2-64I increased the susceptibility of hepatocellular carcinoma. J Surg Oncol 2010; 102: 264-270.

[26] Chung TT, Pan MS, Kuo CL, Wong RH, Lin CW, Chen MK and Yang SF. Impact of RECK gene polymorphisms and environmental factors on oral cancer susceptibility and clinicopathologic characteristics in Taiwan. Carcinogenesis 2011; 32: 1063-1068.

[27] Mohran ZY, Ali-Eldin FA and Abdel Aal HA. Serum interleukin-18: does it have a role in the diagnosis of hepatitis $C$ virus related hepatocellular carcinoma? Arab J Gastroenterol 2011; 12: 29-33.

[28] Bouzgarrou N, Hassen E, Schvoerer E, Stoll-Keller F, Bahri O, Gabbouj S, Cheikh I, Maamouri N, Mammi N, Saffar H, Trabelsi A, Triki H and Chouchane L. Association of interleukin-18 polymorphisms and plasma level with the outcome of chronic HCV infection. J Med Virol 2008; 80: 607-614.

[29] Chisari FV and Ferrari C. Hepatitis B virus immunopathogenesis. Annu Rev Immunol 1995; 13: 29-60.

[30] Bosetti C, Levi F, Boffetta P, Lucchini F, Negri E and La Vecchia C. Trends in mortality from hepatocellular carcinoma in Europe, 1980-2004. Hepatology 2008; 48: 137-145.

[31] Kim YS, Cheong JY, Cho SW, Lee KM, Hwang JC, Oh B, Kimm K, Lee JA, Park BL, Cheong HS, Shin HD and Kim JH. A functional SNP of the Interleukin-18 gene is associated with the presence of hepatocellular carcinoma in hepatitis B virus-infected patients. Dig Dis Sci 2009; 54: 2722-2728.

[32] Karra VK, Gumma PK, Chowdhury SJ, Ruttala R, Polipalli SK, Chakravarti A and Kar P. IL-18 polymorphisms in hepatitis B virus related liver disease. Cytokine 2015; 73: 277-282.

[33] Thio CL, Thomas DL and Carrington M. Chronic viral hepatitis and the human genome. Hepatology 2000; 31: 819-827.

[34] Yang Y and Liu H. Association between interleukin-18 gene promoter (607C/A and - 137G/C) polymorphisms and chronic hepatitis C virus infections: A meta-analysis. Meta Gene 2015; 5: 21-31.

[35] Guidotti LG and Chisari FV. Noncytolytic control of viral infections by the innate and adaptive immune response. Annu Rev Immunol 2001; 19: 65-91.

[36] Bataller R, North KE and Brenner DA. Genetic polymorphisms and the progression of liver fibrosis: a critical appraisal. Hepatology 2003; 37: 493-503.

[37] Migita K, Sawakami-Kobayashi K, Maeda Y, Nakao K, Kondoh S, Sugiura M, Kawasumi R, Segawa O, Tajima H, Machida M, Nakamura M, Yano K, Abiru $\mathrm{S}$, Kawasaki E, Yatsuhashi $\mathrm{H}$, Eguchi $\mathrm{K}$ and Ishibashi $\mathrm{H}$. Interleukin-18 promoter polymorphisms and the disease progression of Hepatitis B virus-related liver disease. Transl Res 2009; 153: 91-96.

[38] Chung JH, Lee YC, Eun YG, Chung JH, Kim SK, Chon S, Oh SJ, Rhee SY and Hong IK. Single Nucleotide Polymorphism of Interleukin-18 and Interleukin-18 Receptor and the Risk of Papillary Thyroid Cancer. Exp Clin Endocrinol Diabetes 2015; 123: 598-603.

[39] Perrella O, Cuomo O, Sbreglia C, Monaco A, Gnarini MR, Gentile B, Perrella M and Perrella A. IL-18 and interferon-gamma in HCV-related hepatocellular carcinoma: a model of interplay between immune status and cancer. J Biol Regul Homeost Agents 2009; 23: 251-258. 